\title{
高出力パルスレーザー光の光ファイバー透過特性 \\ High Powered Laser Pulse Transmittance in \\ Optical Fiber
}

\author{
○平野 達*, 宮木末雄 $*$, 本間 厚 $*$, 加藤治文 $* *$ \\ 會沢勝夫 ${ }^{* *}$, 山下幹雄 ${ }^{* * *}$, 佐藤卓蔵 $* * *$ \\ $\mathrm{O}_{\text {Toru Hirano* }}$, Sueo Miyaki*, Atsushi Honma*., Harubumi \\ Kato**, Katsuo Aizawa**, Mikio Yamashita***, Takuzo Sato*** \\ 浜松ホトニクス(保*, 東京医大**, 電総研*** \\ Hamamatsu Photonics* , Tokyo Medical College**, \\ Electrotechnical Laboratory***
}

\begin{abstract}
An excimer laser pumped dye laser system is used for fluorescence photoradiation or photodynamic theraphy using $\mathrm{HpD}$ which has an affinity for cancer. In this system high powered laser pulse must transmit through an optical fiber to obtain good results of cancer treatment. Quartz fiber of $400 \mu \mathrm{m}$ core diameter could transmit $600 \mathrm{kw}$ laser pulse $(\lambda=620 \mathrm{~nm})$ without damage.
\end{abstract}

:1. $\mathrm{HpD}$ とエキシマ・色素レーザーによるガンの 一方式の特長は 1) レーザーが小型で消費電力が 診断・治㙩

$\mathrm{HpD}$ とレーザー光を用いるガンの診断・治療に 少い，2）低価格，3）高出力パルス光（ピーク 出力約 $1 \mathrm{MW}$ ）に上る深い部位迄の光化学反応治 於いて，診断用のクリプトン・レーザー（波長入 療が期待出来ること等にある。図 1 にてのレーザ 一方式を用いたガンの診断・治療実験装置のブロ $=405 \mathrm{~nm})$, 治療用のアルゴン・色素レーザー（ $\lambda$ ック図を示す2)。

= $620 \mathrm{~nm}$ ), の代りにエキシマ・色素レーザーを エキシマ・レーザー（ 用いる事が出来る1。。の場合には診断，治療の それぞれに適した色素を用いることにより，レー ザー装置は其通に使うことが出来る。このレーザ ギー $50 \mathrm{~mJ}$ /パルス）の励起によって得ら扎る診断 用レーザーにはD P S 色素のジオキサン飽和溶液 が用いられ，エネルギー変換効率 $\eta$ は最大 $38 \%$ が 


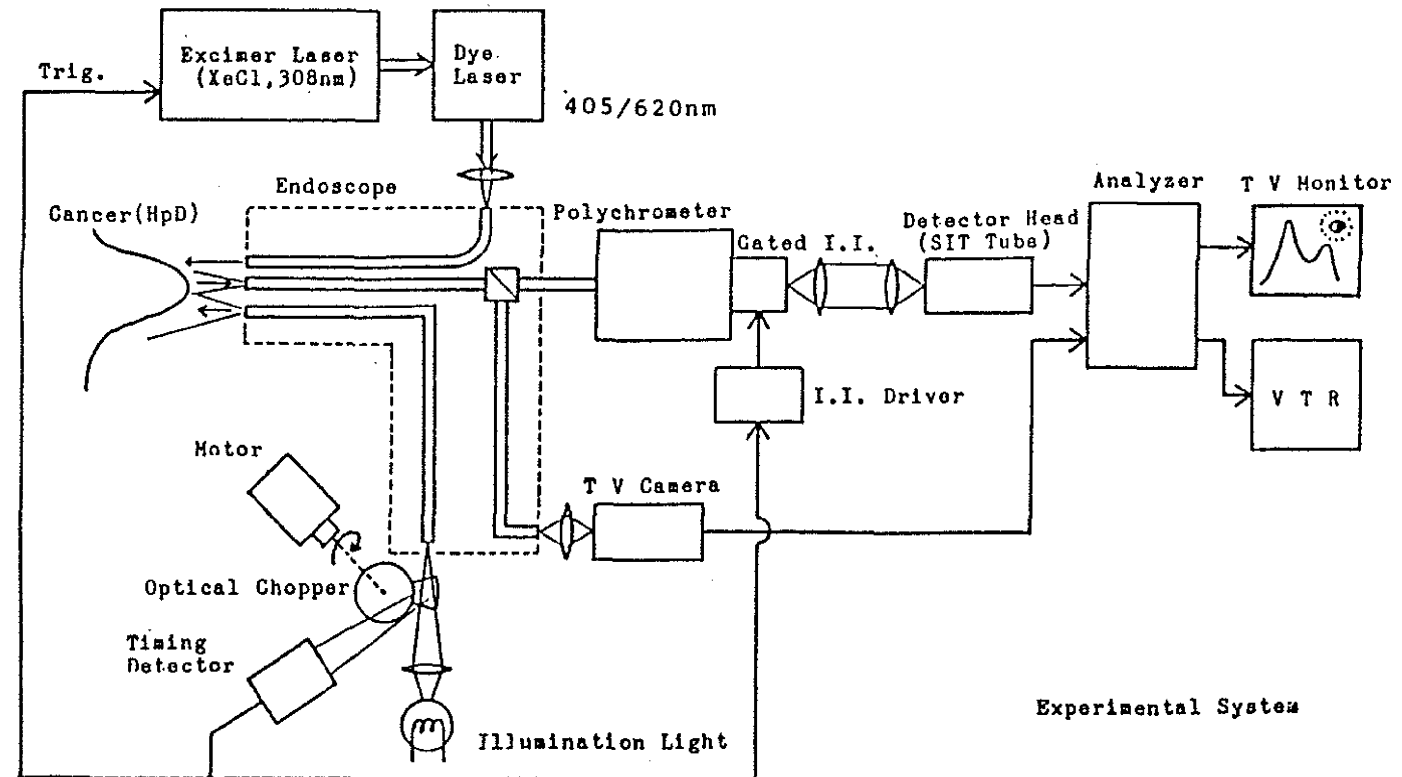

図 1 ガン診断・治療の実験装置

得られている。治療光としてはローダミンB色素 のエチルアルコール溶液を $2 \times 10^{-3} \mathrm{M} / \ell$ 濃度 で使用し， $\eta$ は最大 $26 \%$ が得られる。色素溶液は パルス繰返し特性を良くするためにセルと溶液溜 めの間をステンレス鋼製のポンプで循環されてい る。図 2 はこれらのレーザー光の分光スペクトル を示すむので，DPS 色素は中心波長 $\lambda_{0}=406.9$ $\mathrm{nm}$, 半值波長幅 $\Delta \lambda=11.1 \mathrm{~nm}$, ローダミンB色 素は $\lambda_{0}=624.0 \mathrm{~nm}, \Delta \lambda=12.9 \mathrm{~nm}$ となる。レー ザー共振器にグレーティング等の分散素子を用い ていないので，両者共波長偪の広いレーザー光と なっているが，本実験の目的には差し支えはない。 また中心波長は厳密には $405 \mathrm{~nm}, 620 \mathrm{~nm}$ と異な るが，乙の程度の違いは実用上問題にはならない。 診断時には, あらかじめ $\mathrm{HpD}$ を取り込ませた 組織に，405 nm レーザー光を照射する。ガン部 位は正常部に比べ 10 倍以上の $\mathrm{HpD}$ を取り込むの で, 分光器（ポリクロメータ）を用いて 630,690 $\mathrm{nm}$ にピークを有する $\mathrm{HpD}$ 特有の蛍光パターンを 検出する事により，ガンの診断が可能となる。

ての蛍光パターンは微弱であるので, イメージ 增倍管（II）で增幅され，更に S I T 撮像管を 用いて T V モニタ上に蛍光パターンを表示する事 が出来る。一方レーザー光照射部のイメージを得 るために, 白色光（クセノンランプ光）が照射さ
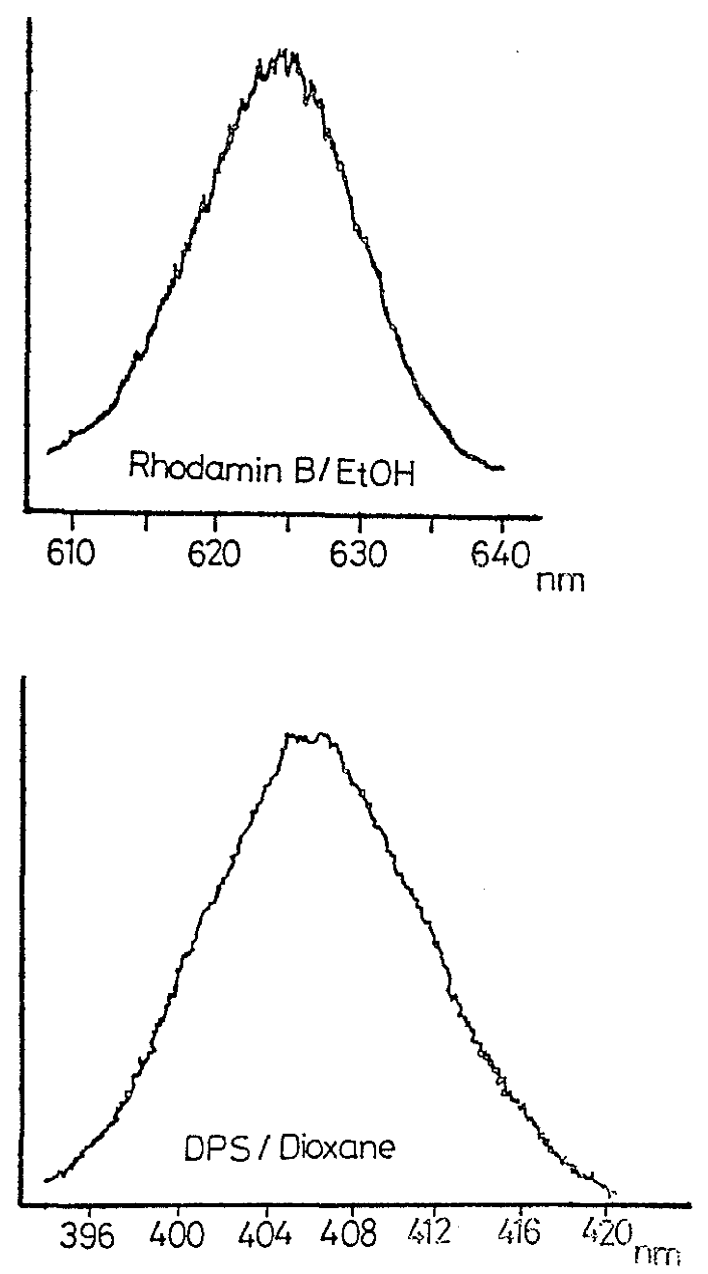

図2 ローダミンB色素レーザー, D P S 色素レ ーザーの分光スペクトル、エキシマ・レーザー エネルギー： $30 \mathrm{~mJ} /$ パルス 


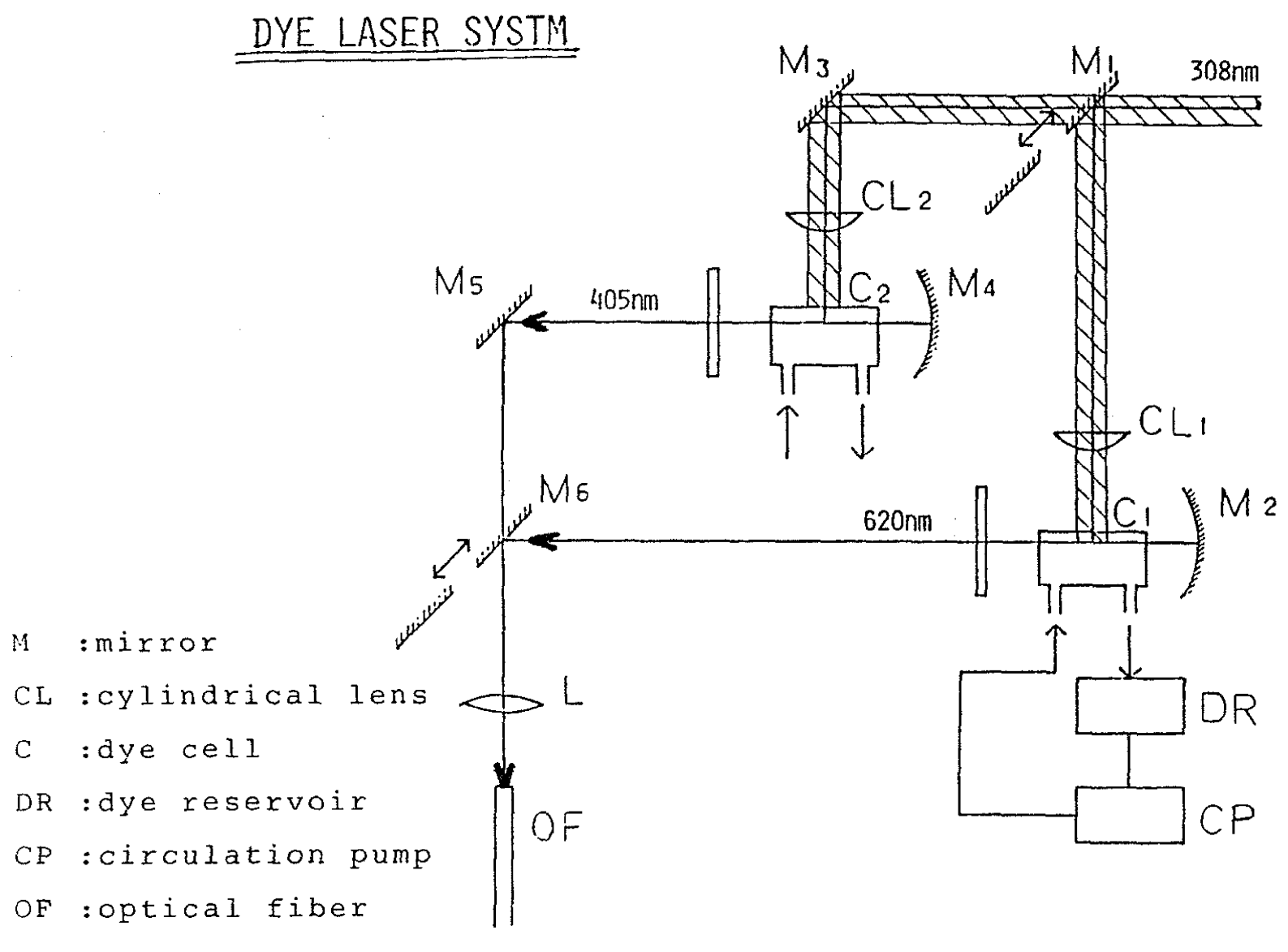

図 3 色素レーザー光学系

れる。反射, 散乱光が $T V$ カメラに導かれ， $\mathrm{T} V$ モニタ上にイメージが表示される。

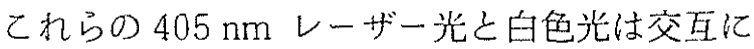
照射され，白色光点灯時には I I への印加電圧の 供給を停止して，II を保護している。ての様に $\mathrm{T} V モ ニ$ タ上は $\mathrm{HpD}$ の蛍光パターンとイメー ジの双方が表示されるので診断が適確となる。

治療時には $620 \mathrm{~nm}$ レーザー光がガン部位に照 射され, 光化学反応による治療が行われる。現在 ネズミ乳ガンに対して樑さ10〜15 mm 位までのガ ンに治瘵効果が得られている。

図 3 は色㨞レーザーの光学系を示すもので, 移 動ステージ上のミラー $M_{1}$ と $M_{6}$ の連動操作に上 り光ファイバーに診断時には $405 \mathrm{~nm}$ が，治療時に は $620 \mathrm{~nm}$ 光が導びかれる。

2. 光ファイバーの透過特性
内視鏡法によって体内にレーザー光を導くとき には，光ファイバーの透過特性が問題亡なる。診 断用レーザー光には大きな出力は必要なく, むし ろ低出力の方が望ましいが，治療光には光化学反 応を有效に行わせるために高出力が必要となる。

パルスレーザー光に対する石英光ファイバーの 最大許容エネルギーは $308 \mathrm{~nm}$ のレーザー光の場 合に, $10 \mathrm{~J} / \mathrm{cm}^{7}$ の值が知られている3 ${ }^{3}$ 。405，620 $\mathrm{nm}$ 光に対してもこの值が適応されるとすると, コアー径 $200 ， 400 ， 600,800 \mu m$ のファイバ 一に対してはそれぞれ 3.1，12.6，28.3，50.3 $\mathrm{mJ}$ となり，乙れ以上の光エネルギーに対しては ファイバーの破損が予想される。実際には長波長 光の方がファイバーの吸収損失は少くなるので, あっと大きな做が許容されるあのと思われるが, 現時点での一応の目安となる。 


\section{3. 実 験}

(1) ファイバー透過測定

光ファイバーに上゙の位の出力のレーザー光パル スが透過出来るか检討した。使用したレーザーは 前記のエキシマ・レーザー励起色素レーザー（ $=405,620 \mathrm{~nm})$ で，光パルス輻はそ㧈ぞれ 4.6 ns， $5.8 \mathrm{~ns}$ である。従って光エネルギー $1 \mathrm{~mJ}$ は 405，620 nm 光でそれぞれ217, $172 \mathrm{KW}$ の゚ー ク出力に相当する。光ファイバーは，大出力用に はコアー径の大きなあのが適すが，内視鏡鉗子ロ

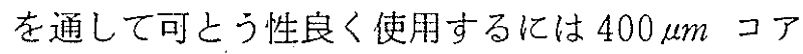
一のものが適している。大日日本電線侏のステッ プインデックス型ファイバーSM 400-SY（コア 一径 $400 \mu \mathrm{m}$, タラッド径 $500 \mu \mathrm{m}$, 長さ $3 \mathrm{~m}$ ) をプ ラグコネクタ $(\mathrm{D}-80 \mathrm{HP})$ に取付けたすのを使 用した。レーザー光エネルギーの测定にはエネル ギーメーター（Gen-Tec，ED-200）を使用し た。

$620 \mathrm{~nm}$ のレーザー光を石英レンズ（大日日本 電線, $\mathrm{D}-80 \mathrm{HL}$, 焦点距離 $\mathrm{f}=20 \mathrm{~mm}$ ) で集光 してファイバー入射面に微小点で入射すると, 出 力 $100 \mathrm{KW}(0.58 \mathrm{~mJ})$ 程度のレーザー光であマイ クロクラックが生じてファイバーが破損する。乙 れは集光部のスポット径を $50 \mu m$ とすれば，乙の 部分でのエネルギー密度は $30 \mathrm{~J} / \mathrm{cm}^{2} に も な り 、 10 \mathrm{~J} /$ cơ゙の破損・許容エネルギーを越すからである。

ファイバーを破損しないためには，咸 4 の様に レンズ焦点よりファイバー端面を離して，コアー 面全体でレーザー光を受けてやればよい。本実験 の $620 \mathrm{~nm}$ 色素レーザー光のビーム径は約 $1.5 \mathrm{~mm}$ （ビーム開き角は半角で約 $0.5 \mathrm{mrad}$ ）であるので $\mathrm{f}=20 \mathrm{~mm}$ のさには，コア一部全面でレーザー 光を受光するにはレンズ焦点とファイバー端面間 距離を $20 \times 0.4 / 1.5=5.3 \mathrm{~mm}$ にして配置すれば よい。現在ての方法でパルス出力 $600 \mathrm{KW}$ 迄使用 しているが破損は媫い。レンズを含めたファイバ 一の透過率は74\%の值が得られている。乙れは連 続発振する $\mathrm{He}-\mathrm{Ne} レ$ レ゙ー光 $(\lambda=633 \mathrm{~nm}$, 出 力 $1 \mathrm{~mW}$ )の透過率 $78 \%$ 上同程度の值であり，遜 色は無い。

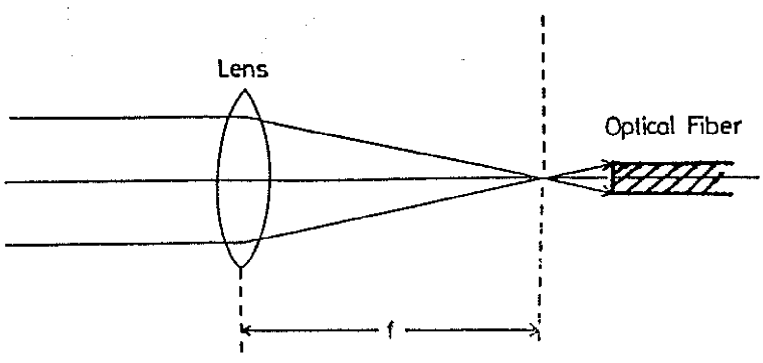

図 4 光ファイバーヘのレーザー光入射

$405 \mathrm{~nm}$ 光の場合には, $620 \mathrm{~nm}$ と同じ方法で, パルス出力 $396 \mathrm{KW}$ 迄ファイバーの破損無く使用 している。

\section{(2) ファイバーの散乱測定}

光ファイバーに強いレーザー光を通すとラマン 散乱が生ずる事が知られている。Pini等はエキシ マ・レーザー ( $\mathrm{XeF}, \lambda=351 \mathrm{~nm}$, ピーク出力 $150 \mathrm{KW}$; Xec $\ell, \lambda=308 \mathrm{~nm}, 350 \mathrm{KW}) \mathrm{N}_{2} レ-$ ザー（ をコアー径 $200 \mu \mathrm{m}$, 長さ $180 \mathrm{~m}$ の石英ファイバ 一 (Quartz and Silice 社製) に通して顕著なラ マン散乱光を得た 次ストークス・シフトは $463 \sim 499 \mathrm{~cm}^{-1}$ の間にあ $\supset た 。$

我々は透過测定に使用した石英ファイバー（コ アー径 $400 \mu \mathrm{m}$, 長さ $3 \mathrm{~m}$ ，大日日本電線製）を用 いて，散乱の检討を行った。診断用の D P S 色素

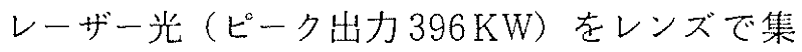
光してファイバー八入射し，その透過光を分光し て闵 5 に示すようなスペクトルを得た。レーザー 波長 $(406.9 \mathrm{~nm})$ より短波長側 $(315.7 \mathrm{~nm})$ と長 波長側 $(498.5 \mathrm{~nm})$ に散乱亡思われるスペクトル が現われている。但し，画者のシフト波数は大き く異なっている。治療用のローダミンB色素レー ザー（ピーク出力 $600 \mathrm{KW}$ ）を用いたときには， レーザー波長 $(615.0 \mathrm{~nm})$ より長い波長（750.0 $\mathrm{nm}$ )でスペクトルを観测した。

これらの結果はPini 等のあのと異なり, シフ 卜波数の統一性も認められないが，ガンの診断・ 治察を行うときの実用上の閥題は少い屯のと思わ 
1. DPS Laser ( $396 \mathrm{~kW})$

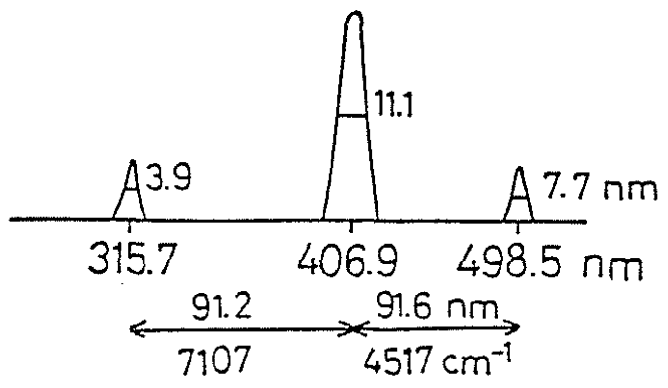

\section{Rhodamin B Laser(600 kW)}

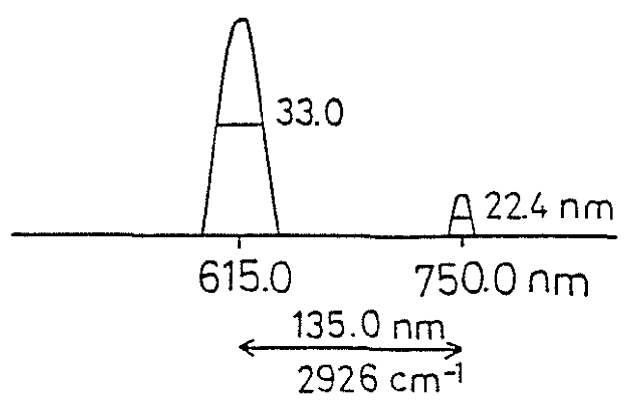

図 5 石英ファイバーの散乱特性

れる。

4. まとめ

1) コアー径 $400 \mu \mathrm{m}$ ，長さ $3 \mathrm{~m}$ の石英ファイ バーにピーク出力 $600 \mathrm{KW}$ のパルスレーザー光が 問題なく透過出来ることを示した（図 5 の測定で は約 10,000パルス光をファイバーに入射している) が，今後更に高出力パルス光の透過，ファイバー 耐久性等の問題が検討されなければならない。

2) ファイバー散乱が何に起因するのか明確に する必要がある。散乱光の定量化も必要である。

\section{参 照 文 献}

1) 會沢, 加藤, 伴野, 大畑, 酒井, 斎藤, 高橋, 大多和，河手，小野，小中，早田，山下, 佐藤, 第 4 回日本レーザー医学会, Sib-3（1983）

2) 平野, 竹島, 本間, 土屋, 會沢, 加藤, 山下, 佐藤，第44回応用物理学会予稿集 p. 181( 1983)

3 ) R. Pini, M. Mazzoni, R. Salimbeni, M. Matera and C.Lin, Appl, Phys, Lett., 43 (1), p. 6 (1983) 